\title{
Examining The Relationship Between Human Resource Management Practices And Organizational Citizenship Behavior For Environment Among Administrative Staff In A Thailand University
}

\author{
Lubna Niyomdecha $a^{a^{*}}$, Khulida Kirana Yahya ${ }^{\mathrm{b}}$ \\ aFaculty of Management Sciences, Phuket Rajhabhat University, Phuket, Thailand \\ ${ }^{b}$ School of Business Management, Universiti Utara Malaysia, 06010 UUM Sintok, Kedah, Malaysia \\ *Corresponding author: lubna.n@pkru.ac.th
}

Article history: Received 25 February 2019 Received in revised form: 05 April 2019 Accepted: 28 May 2019 Published online: 29 August 2019

\begin{abstract}
This study examines the influence of three human resource management practices which are training and development, performance appraisal, and compensation and benefit on organizational citizenship behavior for environment (OCBE) among administrative staffs at Prince of Songkla University (PSU), Hatyai campus. A total of 231 administrative staffs participated in this study. Regression analysis was performed to test the research hypothesis. The results revealed that the two dimensions of human resource management practices which are performance appraisal and compensation and benefit did not have significant relationship with organizational citizenship behavior for environment (OCBE). However, training and development was found to have positive significant relationship with organizational citizenship behavior for environment (OCBE)
\end{abstract}

Keywords: Organizational Citizenship Behavior for Environment (OCBE), training and development, performance appraisal, compensation and benefit

Abstrak

Kajian ini untuk mengkaji pengaruh empat dimensi amalan Pengurusan Sumber Manusia iaitu latihan dan pembangunan, penilaian prestasi dan pampasan serta manfaat kepada Perilaku Kewarganegaraan Kebiasaan Organisasi (OCBE) di kalangan pegawai pentadbiran di Universiti Prince of Songkla (PSU), kampus Hatyai, Thailand. Tujuan penyelidik untuk mengkaji hubungan antara amalan Pengurusan Sumber Manusia (latihan dan pembangunan, penilaian prestasi, pampasan dan faedah). Sejumlah 231 kakitangan pentadbiran telah mengambil bahagian dalam kajian ini. Analisis regresi dilakukan untuk menguji hipotesis penyelidikan. Hasil daripada penemuan ini mendedahkan bahawa kedua-dua dimensi amalan pengurusan sumber manusia (iaitu penilaian prestasi dan pampasan dan faedah) tidak mempunyai hubungan yang signifikan dengan Perilaku Kewarganegaraan Organisasi untuk Alam Sekitar (OCBE). Walau bagaimanapun, latihan dan pembangunan didapati mempunyai hubungan positif dengan Perilaku Kewarganegaraan Kewarganegaraan Awam (OCBE). Kajian ini menyediakan implikasi teoritis dan praktikal.

Kata kunci: Perilaku Kewarganegaraan Organisasi untuk Alam Sekitar (OCBE), latihan dan pembangunan, penilaian prestasi, pampasan dan faedah

(C) 2019 Penerbit UTM Press. All rights reserved

\subsection{INTRODUCTION}

Global warming is the factor used to explain a steadily increasing in the changing temperature of the Earth's atmosphere (Global warming, 2018). It increases rapidly during the last century and become a serious environmental issue worldwide. For the global severe warming issues, organization faces many challenges regarding environment endeavors (Daily et al., 2009) as the increment of pressure from society to improve environmental performance that can lead organizations to increase their encounter with the environmental issues. Generally, environmental issues are mainly caused by the human and industrial activities (Industrial, 2017) that cause organizations must create the best way to solve environmental problems into company's decision-making procedures (Battisti \& Perry, 2011; Fassin, Rossem, \& Buelens, 2011).

Thus, industrialists have selected to observe their environmental impact through the decisions regarding goods design, operation design and operational measures to show their efforts toward environmental initiative as a part of OCBE. Other manufacturers have apparent to build on these competencies and implement a formal program such as the ISO14001 standard system which obviously address environmental concern issues (Marie \& Roy, 2013). In contrast, implementing ISO 14001 standard in the organization contains with a higher cost and some firms believe that the benefits to associate this standard are not ideologically "green" and does not provide a complete system to solve possible problem between environmental and economic dimensions (Perez, Amichai, \& Shterental, 2009). 
Furthermore, the management level is lack understanding the real concept of environment program (i.e., ISO 14001) and it has affected decreasing the willingness of environmental leaders who want to perform the job without stated in job description (Yodpretikarn, 2012) because management's environmental intention and support are incline to stimulate OCBE among employees (Cherian \& Jacob, 2012; Dumont, 2015; Jabbar \& Abid, 2014)

On the other hand, when employee feels that the supervisor's intention regarding environmental issue is pretending, it would have an indirect negative influence employee perspective on OCBE (Lülfs \& Hahn, 2013). Some organizations have been shown their effort on environment initiative as environmental management through policies, goals, contamination avoidance projects, strategies, and sustainable report but there is the part of unplanned, discretionary, and casual activities in the working environment that generally dismiss by employees (Boiral, 2009; Daily et al., 2009; Ramus and Killmer, 2007). Likewise, the organization did not include employee point of view on human resource management (Boiral, Talbot, and Paillé, 2013) to promote OCBE as a green representation of the organization among partners or individual contribution in the environmental activities taken by the organization (Boiral \& Paillé, 2012). It is challenge to create OCBE in all organization level by providing training and development (Arulrajah, Opatha, and Nawaratne, 2015). This is because without an appropriate training and development plan, it cannot enhanced OCBE in organization and without legitimate instruction, training and development, emerging focused on environmental performance are extremely hard to accomplish. Subsequently, it appears that some organizations did not understand the significance of training and development, and education toward OCBE in their organization setting (Zibarras \& Coan, 2015).

The organization setting in terms of performance management, integrating performance appraisal to enhance OCBE among employees has been truly broad (Shen, Netto, \& Tang, 2010) because it is very hard to state the objective of environmental performance standard or voluntary behavior standard and evaluate OCBE in different units of organization (Renwick, Redman \& Maguire, 2008). This is causing to employees' motivation toward environmental concern and it cannot contribute to OCBE among employee (Bangwal \& Tiwari, 2015)

However, Boiral (2009) expressed that compensation and benefit cannot be rewarded to OCBE among employee because this behavior is voluntary and comes from the employees themselves. OCBE as practices that are not perceived by the formal reward framework and the compensation and rewards systems in an organization could not contribute to environmental management. Even though intrinsic and extrinsic rewards encourage and increase the loyalty of workers to have environmentally friendly behavior (Nayak and Res, 2017).

The organization needs to expand comprehensive view of the effect of human resource management practices on OCBE (Paillé, Chen, Boiral, \& Jin, 2014); to explore the relationship between human resource management practices and the scope that employees are possible to engage in OCBE. Currently, there is limited study that examined human resource management practice and OCBE (Zibarras \& Coan, 2015). To the researcher knowledge, OCBE has not researched in Thailand organization in relation to human resource management practices. Thus, this paper will look at the relationship between HRM practices (training and development, performance appraisal, compensation and benefits) and OCBE.

\subsection{LITERATURE REVIEW}

\section{Organizational Citizenship Behavior}

OCBE can be defined as employees' voluntary act which the organization cannot pay or obtain directions to improve the environment (Daily et al., 2009). Likewise, OCBE is the employees' prosocial behavior that engages their colleague in green activities, which could contribute innovative green ideas to green program in the organization (Luu, 2016) so that gaining many benefits as can lead to the sustainable organization (Ramus \& Killmer, 2007).

The elements of OCBE comprise of voluntary, proactive environmental behaviors, and individual performance (Boiral, Talbot, \& Paillé, 2013; Sun et al., 2007). Environmental behaviors may comprise of task such as recycling papers or cans, using proper electronic, and saving energy (Davis, O'Callaghan, \& Knox, 2008). Further, Daily, Bishop, and Govindarajulu, (2009) identified four dimensions of OCBE which including, firstly, environmental concern, organizational commitment, perceived supervisor support for the environmental efforts, and perceived corporate social performance. In the mean time, Boiral and Paillé (2012) argued that eco-initiatives, eco-civic engagement, and eco-helping are the focal types of OCBE. Eco-initiative was interrelated with pro-environmental initiatives driven by an employee and include environmental activities of the organization and could improve the environmental performance. The eco-civic engagement contributed to the environmental initiatives in an organization. It is shown to be necessary to achieve environmental objective because the benefit of developing an inclusive environmental policy is fostering perspective of ecological issues or creating an environmental committee on a voluntary employee by supporting from organizational initiatives. Likewise, the third type of OCBE identified by Boiral and Paillé (2012) was eco-helping, focusing on mutual support among employees who have voluntary mind to assist co-workers to integrate environmental concerns in the workplace and help organization get better result for environmental performance. This study, will utilize types of OCBE based on Boiral \& Paillé (2012) namely the eco-initiatives, eco-civic engagement, and eco-helping.

Many researchers showed that environmental performance and environmental management practices have significant relationship with OCBE (Boiral, 2009; Boiral et al., 2013; Daily et al., 2009; Marie-Jose \& 'e Roy, 2013; Pascal Paillé, Boiral, \& Chen, 2013; Pascal Paillé et al., 2014; Perez et al., 2009) in relation to environmental management and environmental management practices which focused on the role of voluntary and informal individual initiative in the workplace. It can be the official practices aimed to integrate environmental concern into organization management which include environmental management systems such as ISO 1400, environmental reporting, and environmental technology (Boiral, 2009; Paillé et al., 2013).

According to Boiral \& Paillé, (2012), OCBE is employee judgmental behaviors where employee expresses their eagerness to collaborate with their organization and co-worker by doing activities that benefit them and employees may involve in OCBE in many ways. For instance, they might improve on their recommendation and share new practices. Especially when employees feel supported by 
the organization, they will become more committed and engage in OCBE (Paillé \& Boiral, 2013). Further, there is a connection between key human resource management and OCBE (Delaney \& Huselid, 1996). While considering the noteworthy development of organizational citizenship behavior for environment perspective in the association, human resource management practices ought to end up more inventive and good with environmental objectives. It is pivotal for human resource professionals to watch, understand, and embrace the objectives of ace environmental conduct or OCBE to convey workers' esteem to organizations by having adequate information about environmental execution, human resource professionals can hone vital administration exceptionally well and representatives are relied upon to utilize their abilities in reacting to the changing business conditions (Yong \& Yusoff, 2016).

Training and Development

Training is a plan and effort system to adjust or improve knowledge, skill, and abilities of an employee throughout the learning process which is the crucial requirement to perform effectively in the organization (Khulida \& Yean, 2015). According to Salas et al. (2012), to improve employee's productive and satisfaction, organization need to understand that training can support employee because it can remain competitive by continually investing the knowledge in their workers (Aguinis \& Kraiger, 2009). Hence, companies need to invest much more in on-going employee training and development because it can retain good employee and be successful in enhancing organization performance but training and development activities not only improve organizational performance but also enhance individual and team performance in terms of outcome as such attitude, motivation, and empowerment (Aguinis \& Kraiger, 2009).

It can be said that increasing employee's motivation is by organization investing in training and development program and it can improve organizational citizenship behavior for environment (OBCE) and lead to organizational sustainable development (Yazdanifard, 2014). The key area to enhance organizational citizenship behavior for environment (OCBE) is to provide an appropriate training and development in order to make employees more concerned about environment management and environmental effect because they can learn to react to environmental changes and increase awareness of an organization's efforts toward sustainability (Mandip, 2012; Zibarras \& Coan, 2015). This is in line with Arulrajah, Opatha, and Nawaratne (2015) result which show that OCBE influenced by training and development. Therefore, by making environmental mindfulness among the workforce by preparing in that capacity programs and workshops at every level is also critical to accomplish great environmental behavior and giving environmental instruction which can bring about a difference in employees' mind.

Thus the following hypothesis is suggested:

H1:There is significant relationship between training and development with OCBE.

\section{Performance Appraisal}

Performance appraisal is a process of behavior evaluation of staff at the workplace and can be indicated as a means of giving response to employees' performance (Ahmad, 2013). Establishing performance appraisal system for evaluating employee performance need to encounter with three objectives which are strategic, organizational, and developmental purpose because it can help the organization attain its objective by linking employee's behavior with the organization's aim, evaluates staff accomplishment to ascertain which expectations are not being met (Trikas, Papi, Kyriakidis, \& Zachariadis, 2017).

The most important aspect of performance appraisal is to meet the standards of reliability, validity, and impartiality, and effective performance appraisals to deliver useful feedback to employees and support on-going improvements in the firm's environmental outcomes as pro-environmental behavior (Dumont, 2015)but to apply performance appraisal for evaluating organizational citizenship behavior for environment $(\mathrm{OCBE})$ is a big challenge because organization need to create a performance management system to develop OCBE standard and enhance achievement of OCBE in organization (Steg \& Vlek, 2009). Moreover, performance appraisal for evaluating OCBE should focus on the issues of such environmental happenings, environmental everyday jobs, communication of environmental policy, and HR staff need to adjust the performance appraisal evaluating system with comprise of various dimensions for rating people as the following behavioral and technical capabilities: teamwork, participation, diversity, invention, and environmental stewardship (Ahmad, 2015). Such abilities will reinforce the company's core values. Supervisor can critisize the performance of the employees and give the needed feedback not only during the scheduled time of appraisal but also all-around the year. This doing will help the workers increase their proenvironmental behavior (OCBE) and lead to sustainability (Erdogan, Bauer, \& Taylor, 2015).

According to Arulrajah et al. (2015), there is a significant relationship between performance appraisal and OCBE because without performance appraisal, organizations could not guarantee the realistic OCBE in the extended period in that performance appraisal is most significant aspect of performance management to meet the criteria of consistency, validity, and equality (Roberts, 2003). Meanwhile, the adequate performance appraisals deliver useful feedback result to employees and support on-going improvements in the firm's environmental consequences as pro-environmental behavior (Dumont, 2015).

Thus, it is hypothesized that:

H2: performance appraisal will be positively related to OCBE.

\section{Compensation and benefit}

Compensation and benefit is the total compensation system as the package of organization quantifiable rewards and employee will receive from their supervison who use to reward employees from their work performance which include both intrinsic and extrinsic compensation (Khulida \& Yean, 2015). Rewarding desire result and compensation and benefits policies can enhance employee behavior in the workplace, and it can be a tool for motivating job performance to the highest level and enhancing organizational effectiveness (Raymond, 2014). In the means time, organizations want to be more innovative and sustainable company might need to alter their compensation systems to promote more voluntary behavior that can encourage employees to act as a voluntary worker (Roberts, 2003). 
Further, a well design compensation and benefits system can be utilized to promote an employee to perform in a good organizational citizenship behavior for environment practices because it can achieve a greater environmental performance in the organization (Mandip, 2012). The rewarding employee for voluntary behavior will be an essential part of human resource management implementation because it can reinforce empowerment and ethical decision making of the worker to continually motivating their pro-environmental behavior (OCBE) (Cruces, 2001) and be motivating the employee to generate eco-initiative (Ahmad, 2015).

Shen et al. (2010) indicate that compensation and benefit is entirely related to OCBE because it can motivate the employee to create environmental improvement in the organization. Ahmad (2015) said that incentives and rewards can influence OCBE at workplace towards environmental management. Motivating managers and non-managerial employee on environmental management initiatives, the organization needs to create an excellent compensation and benefit program (Jabbour, Santos, \& Nagano, 2010) because rewards and compensation are the fundamental human resource management practices which employees relate to their performance.

Hence, the following hypothesis is postulate:

H3: There is significant influence of compensation and benefit on OCBE

\subsection{THEORETICAL FRAMEWORK}

A research framework is design and develop from the empirical study which shows the relationship between Organizational Citizenship Behavior for Environment (OCBE) Human Resource Management practices of training and development, performance appraisal, compensation and benefit. This framework is further explained in Figure 1.

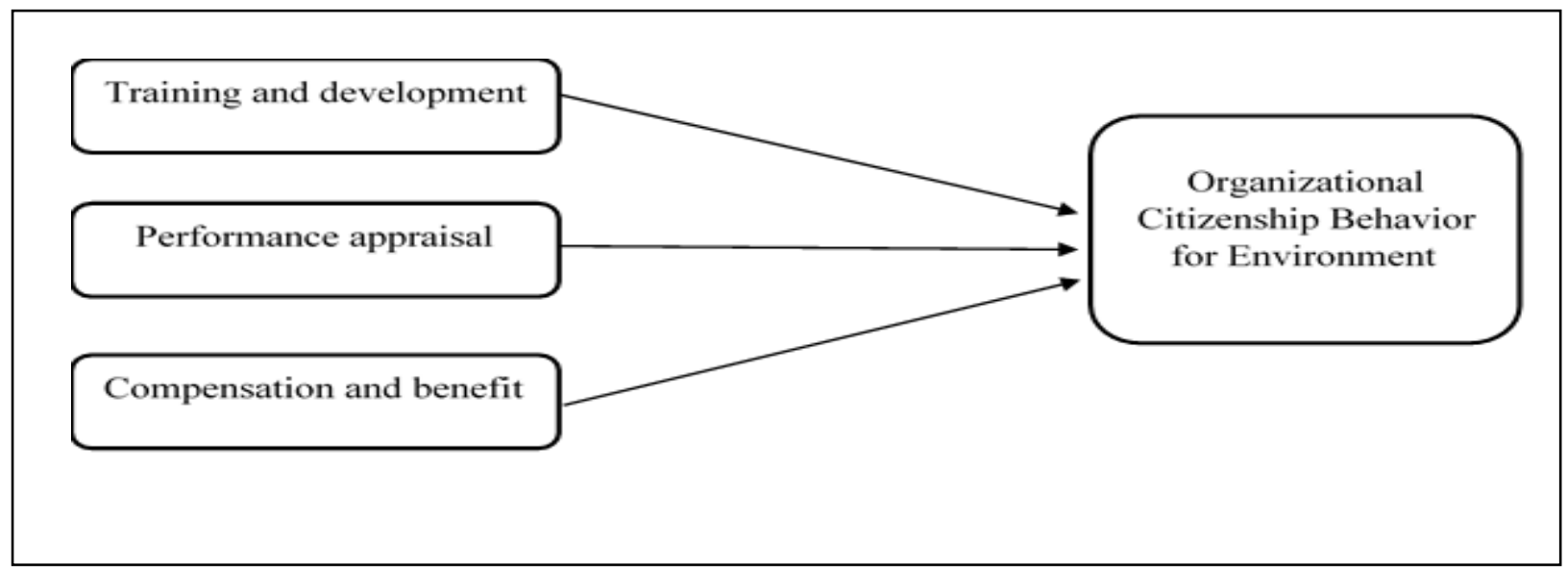

Figure 1 Research framework

\subsection{METHODOLOGY}

Research design

This research is a causal research which intends to identify the relationship between human resource practices and Organizational Citizenship Behavior for the environment )OCBE(. The researcher uses quantitative methods to test the variable and analyze the outcome.

Quantitative research can be defined as the research method dealing with numbers and measurable in a orderly method for researching the geniuses and their connections. It is exploited to answer inquiries on connections inside quantifiable factors with a goal to clarify, anticipate and control wonders connections inside measurable factors with an expectation to explain, foresee and control a phenomenon )Perumal, 2014(. A complete set of a questionnaire is used as an instrument for this study because the questionnaires are more objective, relatively fast to collect information can be collected from a large number of a group )Milne, 1994( and using Statistical Packages of Social Sciences )SPSS( in data analyses.

Population and Sample

Self-administered questionnaires were distributed to the administrative staffs at Prince of Songkla University (PSU), Hatyai campus, Thailand. There are 1,749 administrative staffs at Hatyai campus. Since the population size is 1,749, the Krejcie and Morgan's table (1970) suggested that the targeted sample size should be 313. The sample has been chosen by using Simple Random Sampling )SRS( by collecting questionnaires from respondents. However, a total of 400 questionnaires were distributed to increase the response rate. 


\section{Measurement}

The questionnaires comprised of items to measure OCBE and HRM practices which comprise of training and development, performance appraisal, and compensation and benefits. This study adopted instrument by Boiral and Paille (2012) to evaluate the OCBE. This study embraced the training and development instrument by Demo, Neiva, Nunes, and Rozzett (2012), performance appraisal instrument of five (5) items adopted from Amin, Ismail, Rasid, and Selemani (2014), and measurement by Demo, Neiva, Nunes, and Rozzett (2012) to evaluate the compensation and benefit. Respondents were asked to respond to the items by indicating their level of agreement using a fivepoint Likert scale ( $1=$ strongly disagree to $5=$ strongly agree). To get the accurate answer and ensure respondents understood the instrument in the questionnaire, the questions were translated from the English language to the Thai language.

\section{Data collection}

The survey was conducted at Prince of Songkla University, Hatyai campus, Thailand by sending 400 hard copies of questionnaires to the administrative staffs. A letter was sent to the Office of President, Faculty of Management Sciences, Faculty of Sciences, Faculty of Engineering, and Faculty of Natural Resources to obtain permission for data distribution.

\section{Pilot Test}

A pilot test was conducted in order to examine the validity and reliability of the instrument. A total of 32 questionnaires were distributed via an online survey among administrative staff at PSU, Pattani campus, Thailand from 21st until 23rd March 2018. The online questionnaire was sent to among administrative staffs at student affairs department and the college of Islamic studies. The respondents were given three days to answer the online questionnaires. The reliability test was conducted to determine the validity of the instrument.

Data Analysis

Data was analyzed using SPSS version 23. Various tests were conducted to determine the reliability, validity and relationship between variables. A total of 400 questionnaires were distributed but only 256 questionnaires were returned and only 231 can be used for further analyses.

\subsection{RESULTS AND DISCUSSION}

\section{Descriptive and Reliability Results}

Majority of the respondents are female $150(64.9 \%)$ which only $81(35.1 \%)$ are male respondents. The highest number was from the age range of $31-35$, which $22.1 \%$. (51). In terms of marital status, majority of respondents were married, at $130(56.3 \%)$. While single and divorce statuses were $37.7 \%$ and $6.1 \%$ respectively. Base on the result, 59.3\% of the administrative staffs have worked at Prince of Songkla University more than six years. While $69.3 \%$ had Bachelor degree as the highest level of education.

Table 1 shows the mean and standard deviation results of the study. The reliability results of the measures are also presented (in bold). As shown in Table 2, the Cronbach alpha for OCBE is 0.87 , training and development 0.82 , performance appraisal being 0.86 and compensation and benefit 0.87 . The table also reveals significant positive correlation results between OCBE with the three HRM practices. The results suggested that OCBE and HRM practices have a positive moderate strong significant correlation between 0.29 until 0.488 ( $\mathrm{p} \leq$ $0.01)$.

Table 1 Mean results and standard deviation.

\begin{tabular}{lcc}
\hline Variables & Mean & Standard deviation \\
\hline OCBE & 3.71 & 0.55 \\
Training and development & 3.85 & 0.59 \\
Performance appraisal & 3.97 & 0.68 \\
Compensation and benefit & 3.48 & 0.81 \\
\hline
\end{tabular}

Table 2 Correlations and reliability results

\begin{tabular}{llllll}
\hline No. & Variables & $\mathbf{1}$ & $\mathbf{2}$ & $\mathbf{3}$ & $\mathbf{4}$ \\
\hline 1 & OCBE & $\mathbf{0 . 8 7}$ & $\mathbf{0 . 8 2}$ & & \\
2 & Training and development & $.488^{* *}$ & .494 & $\mathbf{0 . 8 6}$ & \\
3 & Performance appraisal & $.355^{* *}$ & .494 & $\mathbf{0 . 8 7}$ \\
4 & Compensation and benefit & $.297^{* *}$ & .348 & .384 \\
\hline
\end{tabular}




\section{Regression Results}

Multiple regression analysis was carried out to test the hypothesis. The results in Table 3 reveal that $26.6 \%$ ( $\mathrm{R}$ Square $=0.266)$ of the variance in OCBE was explained by training and development, performance appraisal and compensation and benefit. The result indicated that training and development $(\beta=0.389, \mathrm{p}<0.01)$ was positively associated to OCBE indicating being the most significant in influencing OCBE compared to performance appraisal and compensation and benefit. Hence, it can be concluded that OCBE is influenced by training and development, while the other two practices did not influence OCBE. Hence, hypothesis H1 are supported, while H2 and H3 are not supported.

Table 3 Predictors of OCBE regression result

\begin{tabular}{lll}
\hline Independent variables & $\beta$ & $\mathbf{t}$ \\
\hline Training and development & .389 & $5.830^{* *}$ \\
Performance appraisal & .332 & 1.737 \\
Compensation and benefit & .116 & 1.850 \\
\hline Note:**p<0.01; $\mathrm{R}$ Square $=.266 ; \mathrm{R}=.516$ & &
\end{tabular}

\subsection{CONCLUSION}

The result of this study shows that training and development has positive significant relationship with OCBE among administrative staffs at PSU, Hatyai campus because the current vision of Prince of Songkla University is "Green University" which it starts from the "waste separation campaign" to create employee awareness toward overflow garbage problem in university. Prince of Songkla University provides a training and development program to enhance their voluntary behavior for separating the garbage in their workplace. Furthermore, majority of administrative staff had Bachelor degree and have worked at PSU more than six years. Thus, it is easier to understand and perceive an organization investment in their knowledge and development and voluntary to support the university vision. In addition, most of the administrative staffs are willing to integrate the knowledge gained from training and development program in their work to enhance OCBE at Prince of Songkla University.

Besides, this finding is also consistent with Zibarras and Coan (2015) result which show that the significant relationship between organizational citizenship behavior for environment (OCBE) and training and development in UK because the vital area to enhance organizational citizenship behavior for environment (OCBE) is to provide an appropriate training and development to make employees more concerned about environment management and environmental effect. This is because they can learn how to react to environmental changes and increase awareness of an organization's exertions toward sustainability (Mandip, 2012; Zibarras \& Coan, 2015). To increase the organizational citizenship behavior for environment (OCBE) can be done by training and development such as orientation programs and environmental management workshop (Firdaus Abdull Razab, Mohamed Udin, \& Nadzri Osman, 2015)

The result is also in line with Arulrajah, Opatha, and Nawaratne (2015) which showed that organizational citizenship behavior for environment (OCBE)are influenced by training and development in India whereby making environmental mindfulness among the workforce by preparing in that capacity courses and workshops at every hierarchical level is also crucial to accomplishing great environmental behavior and providing environmental instruction can bring about change in the state of employees' awareness. Furthermore, training and development can enhance organizational citizenship behavior for environment (OCBE) and increase employees' value toward environment management (Opatha \& Arulrajah, 2014).

On the other hand, The regression analysis result of performance appraisal with OCBE showed that there is no significant relationship with OCBE at PSU, Hatyai campus, Thailand .It can be said that most of the performance appraisal criteria in university are set based on academic performance perspective and not environmental performance which makes it difficult to measure OCBE in organization. Husin (2012) and Shen, Netto, and Tang (2016) supported this study that there is no significant relationship path of performance appraisal to OCBE because it has been widely known to integrated performance appraisal to enhance OCBE among employee. Shen et al., (2010) meanwhile, calso examined that it is very difficult to state the objective of environmental performance standard and evaluate OCBE in different units of the organization. This cause employees 'motivation toward environmental concern and cannot contribute to OCBE because without clearly purpose environmental management, it cannot guide employee performance to the environmental performances need by the organization (Jabbour, Bangwal \& Tiwari, 2015)

Furthermore, Form the result of this study, there is no relationship between compensation and benefit with OCBE at Prince of Songkla University, Hatyai campus, Thailand because Organizational Citizenship Behavior for Environment is an unrewarded behavior. This is similar to Boiral et al.(2013) study that there is no significant positive relationship between compensation and benefit and OCBE . This result showed that compensation and benefit could not influence OCBE among administrative staff at Prince of Songkla University, Hatyai campus, Thailand because OCBE is voluntary behavior that drives from employee willingness and not from any remuneration (Paillé et al., 2014).

In conclusion, the results support that training and development effect on OCBE. This paper has shed light on the importance of training and development on employee activities to boost their OCBE. This could be included in the organization policy about the importance of this attribute to achieve smooth participation among staff on their environment activities. Furthermore, support from top management will be ensured that staffs pass through the training and development program to support the environmental programs. By creating awareness and training and developing staff with the right skills and attitude will ensure environmental and green policies be implemented and accepted by all staff at PSU. 


\section{References}

Aguinis, H., \& Kraiger, K. (2009). Benefits of Training and Development for Individuals and Teams, Organizations, and Society. Annual Review of Psychology, 60(1), 451-474. https://doi.org/10.1146/annurev.psych.60.110707.163505

Ahmad, R. (2013). Issues and Challenges in the Practice of Performance Appraisal Activities in the 21 st Century . International Journal of Education and Research, $1(4), 1-8$.

Ahmad, S. (2015). Green Human Resource Management: Policies and Practices. Cogent Business \& Management, 2(1), 1-13. https://doi.org/10.1080/23311975.2015.1030817

Arulrajah, A. A., Opatha, H. H. D. N. P., \& Nawaratne, N. N. J. (2015). Green Human Resource Management Practices : A Review Literature Review on Green HRM Practices. Sri Lankan Journal of Human Resource Management, 5(1), 1-16.

Bangwal, D., \& Tiwari, P. (2015). Green HRM - A Way To Greening The Environment. IOSR Journal of Business and ManagementVer. I, 17(12), 2319-7668. https://doi.org/10.9790/487X-171214553

Battisti, M., \& Perry, M. (2011). Walking the talk? Environmental Responsibility From The Perspective Of Small-Business Owners. Corporate Social Responsibility and Environmental Management, 18(3), 172-185. https://doi.org/10.1002/csr.266

Battles, J., Robards, T., Das, A., \& Waring, K. (2006). Climate Change Impact On Forest Resources. Change Center White, (November 2008).

Boiral, O. (2009). Greening the Corporation Through Organizational Citizenship Behaviors. Journal of Business Ethics, 87(2), 221-236. https://doi.org/10.1007/s10551-008-9881-2

Boiral, O., \& Paillé, P. (2012). Organizational Citizenship Behaviour for the Environment: Measurement and Validation. Journal of Business Ethics, 109(4), 431-445. https://doi.org/10.1007/s10551-011-1138-9

Boiral, O., Talbot, D., \& Paillé, P. (2013). Leading by Example: A Model of Organizational Citizenship Behavior for the Environment. Business Strategy and the Environment, 24(6), 532-550. https://doi.org/10.1002/bse.1835

Carbery, R., \& Cristine. (2015). Human Resource Development A Conside Introduction. Plagrve: Macmillan Publishers Limited.

Cherian, J. P., \& Jacob, J. (2012). A Study of Green HR Practices and Its Effective Implementation in the Organization: A Review. International Journal of Business and Management, 7(21), 25-33. https://doi.org/10.5539/ijbm.v7n21p25

Cruces, L. (2001). Achieving Sustainability Through Attention To Human Resource Factors In Environmental Management, $21(12), 1539-1552$.

Daily, B. F., Bishop, J. W., \& Govindarajulu, N. (2009). A Conceptual Model For Organizational Citizenship Behavior Directed Toward The Environment. Business and Society, 48(2), 243-256. https://doi.org/10.1177/0007650308315439

Dumont, J. (2015). Employee Workplace Outcomes.

Erdogan, B., Bauer, T. N., \& Taylor, S. (2015). Management Commitment To The Ecological Environment And Employees: Implications For Employee Attitudes And Citizenship Behaviors. Human Relations, 68(11), 1669-1691. https://doi.org/10.1177/0018726714565723

Fassin, Y., Van Rossem, A., \& Buelens, M. (2011). Small-Business Owner-Managers' Perceptions of Business Ethics and CSR-Related Concepts. Journal of Business Ethics, 98(3), 425-453. https://doi.org/10.1007/s10551-010-0586-y

Firdaus Abdull Razab, M., Mohamed Udin, Z., \& Nadzri Osman, W. (2015). Understanding the Role of Ghrm Towards Environmental Performance. Journal of Global Business and Social Entrepreneurship (GBSE), 1(2), 118-125. Retrieved from http://gbse.com.my/isi16/GBSE 1(2), 118-125 (2015).pdf

Global warming. (2018, february). Retrieved from livescience: https://www.livescience.com/topics/global-warmin.

Gomes-Mejia, L. R., Balkin, D. B., \& Cardy, R. L. (2012). Managing Human Resources. New York: Pearson.

Gomez-Meija, L. R., \& Welbourne, T. (1991). Compensation Strategies in a Global Context.

Husin, S. (2012). HRM Practices, Organizational Citizenship Behaviors , and Perceived Service Quality in Golf Courses, 143-158.

Industrial, d. o. (2017, january). statistic of complaint. Retrieved from department of industrial works: http://www.diw.go.th/hawk/content.php?mode=claim60

Jabbar, M. H., \& Abid, M. (2014). GHRM : Motivating Employees towards Organizational Environmental Performance. MAGNT Research Report, 2(4), 267-278.

Jabbour, C. J. C., Santos, F. C. A., \& Nagano, M. S. (2010). Contributions of HRM throughout the stages of environmental management: Methodological triangulation applied to companies in Brazil. International Journal of Human Resource Management, 21(7), 1049-1089. https://doi.org/10.1080/09585191003783512

Kaur, S., \& Kaur, H. (2016). Climate Change, Food Security, and Water Management in South Asia: Implications for Regional Cooperation. Emerging Economy Studies, 2(1), 1-18. https://doi.org/10.1177/2394901516628256

Lülfs, R., \& Hahn, R. (2013). Corporate greening Beyond Formal Programs, Initiatives, And Systems: A Conceptual Model For Voluntary Pro-Environmental Behavior Of Employees. European Management Review, 10(2), 83-98. https://doi.org/10.1111/emre.12008

Mandip, G. (2012). Green HRM : People Management Commitment to Environmental Sustainability. Research Journal of Recent Sciences, 1, $244-252$.

Marie-Jose, \& 'e Roy, O. B. and P. P. (2013). Pursuing Quality And Environmental Performance Initiatives And Supporting Processes. Business Process Management Journal, 19(1), 30-53. https://doi.org/http://dx.doi.org/10.1108/VINE-10-2013-0063

Nayak, S., Res, V. M.-I. J. S., \& 2017, undefined. (2017). Green Hrm for Business Sustainability. Ijsr.In, 15(2), 102-105. Retrieved from https://www.ijsr.in/upload/675798464Chapter_17.pdf

Noe, R. A. (2010). Employee Training and Development. (Seventh, Ed.) New York: McGraw Hill Education.

Opatha, H. H. D. N. P., \& Arulrajah, A. A. (2014). Green Human Resource Management: Simplified General Reflections. International Business Research, 7(8), 101112. https://doi.org/10.5539/ibr.v7n8p101

Paillé, P., \& Boiral, O. (2013). Pro-Environmental Behavior At Work: Construct Validity And Determinants. Journal of Environmental Psychology, 36, 118-128. https://doi.org/10.1016/j.jenvp.2013.07.014

Paillé, P., Boiral, O., \& Chen, Y. (2013). Linking Environmental Management Practices And Organizational Citizenship Behaviour For The Environment: A Social Exchange Perspective. International Journal of Human Resource Management, 24(18), 3552-3575. https://doi.org/10.1080/09585192.2013.777934

Paillé, P., Chen, Y., Boiral, O., \& Jin, J. (2014). The Impact of Human Resource Management on Environmental Performance: An Employee-Level Study. Journal of Business Ethics, 121(3), 451-466. https://doi.org/10.1007/s10551-013-1732-0

Paillé, P., Raineri, N., \& Boiral, O. (2017). Environmental Behavior On and Off the Job: A Configurational Approach. Journal of Business Ethics, (0123456789) https://doi.org/10.1007/s10551-017-3758-1

Perez, O., Amichai-Hamburger, Y., \& Shterental, T. (2009). The Dynamic of Corporate Self-Regulation: ISO 14001, EnvironmentallnCommitment, and Organizational Citizenship Behavior. Law \& Society Review, 43(3), 593-629.

Ramus, C. A., \& Killmer, A. B. C. (2007). Corporate Greening Through Prosocial Extrarole Behaviours - A Conceptual Framework For Employee Motivation. Business Strategy and the Environment, 16(8), 554-570. https://doi.org/10.1002/bse.504

Raymond, S. (2014). Human Resource Management. Australia: WIiley.

Renwick, D., Redman, T., \& Maguire, S. (2008). Green HRM : A Review , Process Model, And Research Agenda, 44(0), 1-46.

Renwick, D. W. S., Redman, T., \& Maguire, S. (2013). Green Human Resource Management: A Review and Research Agenda*. International Journal of Management Reviews, 15(1), 1-14. https://doi.org/10.1111/j.1468-2370.2011.00328.x

Roberts, G. E. (2003). Employee Performance Appraisal System Participation:A Technique that Works. Public Personnel Management, 32(1), 89-98. https://doi.org/10.1177/009102600303200105

Shen, J., Netto, B. D., \& Tang, J. (2010). Human Effects of Human Resource Diversity Management On Organizational Citizen Behaviour In The Chinese Context, (November 2014), 37-41. https://doi.org/10.1080/09585192.2010.509622

Society For Human Resource Management. (2017). 2017 Employee Benefits, 1-33. Retrieved from https://www.shrm.org/hr-today/trends-and-forecasting/researchand-surveys/Documents/2017 Employee Benefits Report.pdf 
Sun, L.-Y., Aryee, S., Law, K. S., Li-Yun, S. U. N., Aryee, S., \& Law, K. S. (2007). High-Performance Human Resource Practices, Citizenship Behavior, And Organizational Performance: A Relational Perspective. Academy of Management Journal, 50(3), 558-577. https://doi.org/10.5465/AMJ.2007.<strong>25525821</strong>

Trikas, E. D., Papi, R. M., Kyriakidis, D. A., \& Zachariadis, G. A. (2017). Evaluation of Ion Exchange and Sorbing Materials for Their Adsorption/Desorption Performane towards Anthocyanins, Total Phenolics, and Sugars from a Grape Pomace Extract. Separations, 4(1), 9. https://doi.org/10.3390/separations4010009

Khulida, K. Y., \& Yean, T. F. (2015). Enhancing Career Commitment: The Influence Of Human Resource Mangement Practices. International Journal of Business and Society, 16(2), 237-246.

Yazdanifard, R. (2014). the Impact of Employee Training and Development on Employee. Research Gate (check spelling), 2(6), 91-93. https://doi.org/10.6007/IJARBSS/v6-i1/1987

Yodpretikarn, P. (2012). CSR and Sustainable Development. Sukhothai Thammathirat Economic, 1-10.

Zibarras, L. D., \& Coan, P. (2015). HRM Practices Used To Promote Pro-Environmental Behavior: A UK Survey. International Journal of Human Resource Management, 26(16), 2121-2142. https://doi.org/10.1080/09585192.2014.972429 